\begin{tabular}{|l|l|}
\hline Jurnal Bimbingan dan Konseling Ar-Rahman \\
Volume 6, Nomor 1, Tahun 2020 \\
Tersedia Online: http://ojs.uniska.ac.id/index.php/BKA \\
e-ISSN 2477-6300
\end{tabular}

\title{
HUBUNGAN ANTARA PERKEMBANGAN MORAL DENGAN PERILAKU PROSOSIAL SISWA KELAS X REKAYASA PERANGKAT LUNAK SMK NEGERI 1 TENGARAN
}

\author{
Ivan Azariya $^{1}$, Tritjahjo Danny Soesilo ${ }^{2}$, Setyorini ${ }^{3}$ \\ Program Studi Bimbingan dan Konseling FKIP-Universitas Kristen Satya Wacana, Jl. Diponegoro 52-60 \\ Salatiga 50711, Jawa Tengah -Indonesia \\ ${ }^{1} 132016001 @$ student.uksw.edu \\ tritjahjo.danny@uksw.edu \\ 3setyorini@staff.uksw.edu
}

\begin{abstract}
ABSTRAK
Penelitian ini bertujuan untuk mengetahui signifikansi hubungan antara perkembangan moral dengan perilaku prososial. Teknik sampling didalam penelitian ini menggunakan Teknik total sampling. Pengambilan datanya dengan cara langsung membagikan skala kepada semua siswa. Subyek penelitian ini adalah seluruh siswa kelas X Rekayasa Perangkat Lunak SMK Negeri 1 Tengaran Tahun Pelajaran 2019/2020 yang berjumlah 129 siswa. Pendekatan penelitian ini adalah kuantitatif korelasional dengan teknik korelasi kendall tau b. Hasil penelitian menunjukkan bahwa ada hubungan yang signifikan antara perkembangan moral dengan perilaku prososial siswa kelas X Rekayasa Perangkat Lunak SMK Negeri 1 Tengaran Tahun Pelajaran 2019/2020 dengan koefisien korelasir $=0.291$ dan $p=0.001<0.01$. Dengan demikian hipotesis yang diajukan diterima. Hal ini berarti bahwa perkembangan moral memiliki hubungan yang signifikan dengan perilaku prososial siswa SMK Negeri 1 Tengaran.
\end{abstract}

Kata Kunci : Perilaku Prososial; Perkembangan Moral; Siswa SMK

\begin{abstract}
This study aims to determine the significance of the relationship between moral development and prosocial behavior. The subjects of this study were all grade X students of Software Engineering at State Vocational School 1 Tengaran in the 2019/2020 Academic Year totaling 129 students. This type of research is correlational research with the Kendall tau correlation technique $b$. The results showed that there was a significant relationship between moral development and prosocial behavior of the tenth grade students of Software Engineering at State Vocational High School 1 in 2019/2020 Academic Year with correlation coefficient $=0.291$ and $p=0.001<0.01$. That is, the higher the level of moral development, the higher the level of prosocial behavior, or conversely the lower the level of moral development, the lower the level of social behavior.
\end{abstract}

Keywords: Moral Development; Prosocial Behavior; Vocational High-School Student 
Ivan Azariya, Tritjahjo Danny Soesilo, Setyorini Jurnal Bimbingan dan Konseling Ar-Rahman

Volume, Nomor, Tahun Edisi

e-ISSN 2477-6300

\section{PENDAHULUAN}

Dalam kehidupan sehari-hari manusia membutuhkan perkembangan moral dan perilaku prososial yang baik untuk berinteraksi dengan sesama terutama pada usia remaja. Melalui interaksi sosial dengan orang tua, guru, teman sebaya, ataupun orang lain mereka akan lebih mengenal tentang nilai-nilai moral atau konsepkonsep moralitas, seperti kesopanan, kejujuran, keadilan, dan kedisiplinan. Menurut Eisenberg dan Mussen (1989) perkembangan moral mempengaruhi kecenderungan hati seseorang untuk bertindak secara prososial.

Menurut Kohlberg (1995) perkembangan moral sebagai penalaran terhadap nilai, penilaian sosial dan juga penilaian terhadap kewajiban yang mengikat individu dalam melakukan sebuah tindakan. Menurut Santrock (2011) menilai perkembangan moral sebagai perkembangan yang berkaitan dengan aturan dan konvensi mengenai apa yang seharusnya dilakukan oleh manusia dalam interaksinya dengan orang lain.

Saat memasuki masa remaja, individu diharapkan dapat mengganti konsep moral yang berlaku dimasa kanak-kanak dengan prinsip moral yang berlaku umum dan merumuskan kode-kode moral yang berfungsi bagi pedoman perilakunya. Seorang remaja yang sebelumnya menjadi tanggung jawab orang tua dan guru harus dapat mengendalikan perilakunya sendiri. Pada masa remaja muncul dorongan untuk melakukan perbuatan-perbuatan yang dapat dinilai baik oleh orang lain (Syamsu Yusuf 2002). Remaja berperilaku bukan hanya untuk memenuhi kepuasaan fisiknya, tetapi sekaligus rasa puas dengan adanya penerimaan dan penilaiaan positif dari orang lain tentang perbuatannya.

Perilaku prososial adalah suatu tindakan menolong yang menguntungkan orang lain tanpa harus menyediakan suatu keuntungan langsung pada orang yang melakukan tindakan tersebut, dan mungkin bahkan melibatkan suatu resiko bagi orang yang menolongnya (Baron \& Byrne 2003).

Menurut hasil penelitian yang dilakukan oleh Setioasih (2016) tentang Hubungan antara Perkembangan Moral dengan Perilaku Prososial pada Remaja, yang melibatkan 250 remaja, menemukan bahwa ada hubungan positif antara perkembangan moral dengan perilaku prososial pada remaja dengan koefisien korelasi 0,822 . Uji signifikansi menunjukkan hasil $0,000 \quad(\mathrm{p}<0,01)$ berarti korelasi kedua variabel signifikan.

Penelitian yang dilakukan oleh Kusumastuti (2017) tentang Hubungan antara Perkembangan Moral dengan Perilaku Proposial pada Dewasa Awal, yang melibatkan 152 partisipan dengan kriteria usia 18 tahun sampai 40 tahun, menemukan koefisien korelasi (rxy) sebesar 0,061 dengan signifikansi sebesar $0.458(>0,05)$ yang artinya tidak signifikan. Berdasarkan hasil penelitian tersebut, didapatkan hasil bahwa perkembangan moral dengan perilaku prososial tidak berhubungan.

Berdasarkan hasil wawancara dengan guru BK di kelas X Rekayasa Perangkat Lunak SMK Negeri 1 Tengaran Tahun Pelajaran 2019/2020 banyak siswa yang tidak memiliki kesadaran untuk menolong satu sama lain secara sukarela, contohnya seperti saat ada teman yang mau akan pergi membeli makanan di kantin jika ada yang ingin menitip makanan kebanyakan ingin mendapat imbalan seperti uang kembaliannya. Sehingga menyebabkan siswa tersebut tidak memiliki perkembangan moral yang baik, yang seharusnya siswa tersebut tidak meminta imbalan, serta saat sedang latihan praktek membuat website siswa yang sudah bisa tidak mau membantu siswa lain yang masih kesusahan dalam membuatnya jika tanpa sepengetahuan guru pengajar. Selain hasil wawancara dengan guru BK, untuk jurusan Rekayasa Perangkat Lunak jika nantinya saat magang atau memasuki dunia kerja membutuhkan perkembangan moral yang baik karena akan bertemu dengan orang-orang baru dan perilaku prososial yang baik untuk saling membantu tidak hanya fokus terhadap pekerjaan tanggung jawabnya saja melainkan pekerjaan lain yang dirasa membutuhkan bantuan dalam pengerjaannya.

Perilaku prososial adalah suatu tindakan menolong yang menguntungkan orang lain tanpa harus menyediakan suatu keuntungan langsung pada orang yang melakukan tindakan tersebut, dan mungkin bahkan melibatkan suatu resiko bagi orang yang menolongnya (Baron \& Byrne 2003). Gerungan (2004) mengemukakan bahwa perilaku prososial mencakup perilaku yang menguntungkan orang lain yang mempunyai konsekuensi sosial yang positif sehingga akan menambah kebaikan fisik ataupun psikis. Menurut Fabes \& Eisenberg (1998) perilaku prososial adalah tindakan yang memberikan keuntungan pada pihak lain yang terdiri dari berbagi, menyumbang, dukungan emosional atau belarasa, pertolongan dan ketersediaan diri untuk membantu. Perilaku prososial umumnya diperoleh melalui proses belajar (Lestari 2015). Seseorang dikatakan berperilaku prososial jika individu tersebut menolong individu lain tanpa memperdulikan motif-motif si penolong timbul karena adanya penderitaan, yang dialami oleh orang lain meliputi saling membantu, menghibur, persahabatan,

Dipublikasikan Oleh :

UPT Publikasi dan Pengelolaan Jurnal

Universitas Islam Kalimantan Muhammad Arsyad Al-Banjari Banjarmasin 
penyelamatan, pengorbanan, kemurahan hati, dan saling membagi (Yuli Asih 2010). Perilaku prososial juga dapat berfungsi sebagai penolong individu untuk melakukan kebaikan agar diterima dilingkungan masyarakat (Elistantia 2018).

Terdapat aspek-aspek perilaku prososial menurut Eisenberg (dalam Faturochman 2006) meliputi sharing (membagi), helping (menolong), honesty (kejujuran), cooperative (kerjasama), generosity (kedermawanan) dan mempertimbangkan hak dan kesejahteraan orang lain. Sedangkan Eisenberg \& Mussen (1989) menyatakan terdapat faktor yang mempengaruhi perilaku prososial yaitu faktor biologis, budaya masyarakat setempat, pengalaman sosialisasi, proses kognitif, respon emosional, karakteristik individu, dan faktor situasional.

Menurut Kohlberg (1995) mendefinisikan perkembangan moral sebagai penalaran terhadap nilai, penilaian sosial dan juga penilaian terhadap kewajiban yang mengikat individu dalam melakukan sebuah tindakan. Perkembangan moral orientasinya untuk mengungkapkan moral yang hanya ada dalam pikiran dan yang dibedakan dengan tingkah laku moral dalam arti perbuatan nyata. Semakin tinggi tahap perkembangan moral seseorang, akan semakin terlihat moralitas yang lebih mantap dan bertanggung jawab dari perbuatan-perbuatannya (Kohlberg dalam Desmita 2015). Moral adalah perilaku yang sesuai dengan kode moral kelompok sosial, berarti tata cara, kebiasaan, dan adat (Aridhona 2017). Perilaku sikap moral berarti perilaku yang sesuai dengan kode moral kelompok sosial yang dikembangkan oleh konsep moral yang artinya peraturan perilaku yang menjadi kebiasaan bagi anggota suatu budaya (Maharani 2014). Menurut Santrock (2011) menilai perkembangan moral sebagai perkembangan yang berkaitan dengan aturan dan konvensi mengenai apa yang seharusnya dilakukan oleh manusia dalam interaksinya dengan orang lain. Ketika manusia dilahirkan, manusia tidak memiliki moral akan tetapi dalam dirinya terdapat potensi moral yang siap untuk dikembangkan (Waty 2017).

Terdapat tahap perkembangan moral menurut Kohlberg (dalam Desmita 2015) mencakup pra-konvensional moralitas, konvensional, dan pasca konvensional. Sedangkan Syamsu Yusuf (2011) menyatakan faktor-faktor yang mempengaruhi perkembangan moral yaitu konsistensi dalam mendidik, sikap orang tua dalam keluarga, penghayatan dan pengalaman agama yang dianut, dan sikap konsisten orang tua dalam menerapkan norma.

\section{METODE}

Jenis penelitian ini adalah penelitian korelasional. Menurut Soesilo (2018) penelitian korelasional merupakan suatu penelitian yang bertujuan untuk menyelidiki (membuktikan) sejauh mana keterkaitan atau keeratan hubungan suatu variabel dengan satu atau lebih variabel lain.

Populasi dalam penelitian ini adalah seluruh siswa kelas X Rekayasa Perangkat Lunak SMK Negeri 1 Tengaran Tahun Pelajaran 2019/2020 yang terdiri dari empat kelas berjumlah 129 siswa dan teknik sampling didalam penelitian ini menggunakan Teknik total sample.

Teknik pengumpulan data menggunakan teknik metode skala. Skala terdiri dari 2 jenis yaitu, skala perkembangan moral terdiri dari 36 item pernyataan dibagi menjadi 2 yaitu 18 item favorabel dan 18 item unfavorabel dan skala perilaku prososial terdiri dari 36 item pernyataan dibagi menjadi 2 yaitu 18 item favorabel dan 18 item unfavorabel. Skala perkembangan moral yang digunakan dalam penelitian ini mengadaptasi dari Amzori (2014) dan skala perilaku prososial diadaptasi dari Setioasih (2016) .

Uji validitas mengacu pada teori Azwar (2000) koefisien korelasi item pernyataan >0,30. Skala Perkembangan Moral sebanyak 36 pernyataan valid karena $r>0,30$. Skor validitas tertinggi yaitu 0,687 dan skor validitas terendah yaitu 0,323. Skala Perilaku Prososial sebanyak 36 pernyataan valid karena $r>0,30$. Skor validitas tertinggi yaitu 0,752 dan skor validitas terendah yaitu 0,334 . Uji reliabiltas mengacu pada teori Azwar (2000) dengan hasil kedua skala memiliki reliabilitas > 9 dan berada pada kategori sangat baik. Reabilitas untuk skala perkembangan moral yaitu sebesar 0,921 dan untuk skala perilaku prososial yaitu sebesar 0,928.

Teknik analisis data yang digunakan dalam penelitian dengan teknik korelasi kendall tau $b$ karena sifatnya ordinal (Soesilo 2018), menggunakan SPSS 20 for windows (Statistical Product and Service Solution).

\section{HASIL DAN PEMBAHASAN}

Penelitian ini dilakukan pada seluruh siswa kelas X Rekayasa Perangkat Lunak SMK Negeri 1 Tengaran Tahun Pelajaran 2019/2020 yang berjumlah 129 siswa yang terdiri dari empat kelas . Kelas X Rekayasa Perangkat Lunak 1 yang terdiri dari 18 siswa perempuan dan 14 siswa laki-laki, $X$ Rekayasa Perangkat Lunak 2 yang terdiri dari 18 siswa perempuan dan 15 siswa laki-laki, X Rekayasa Perangkat Lunak 3 yang terdiri dari 19 siswa perempuan dan 14 siswa laki-laki, dan $\mathrm{X}$ Rekayasa Perangkat Lunak 4 yang terdiri dari 17 siswa perempuan dan 14 siswa laki-laki. 
Ivan Azariya, Tritjahjo Danny Soesilo, Setyorini Jurnal Bimbingan dan Konseling Ar-Rahman Volume, Nomor, Tahun Edisi

e-ISSN 2477-6300

Berdasarkan analisis deskriptif diketahui hasil sebagai berikut:

Tabel 1. Daftar Distribusi Frekuensi Kecenderungan Kategori Perkembangan Moral

\begin{tabular}{cccc}
\hline Kategori & Kelas Interval & Frekuensi & Presentase (\%) \\
\hline Sangat Tinggi & $\mathrm{X} \geq 151.2$ & 2 & $1.6 \%$ \\
Tinggi & $122.4 \leq \mathrm{X}<151.2$ & 101 & $78.3 \%$ \\
Sedang & $93.6 \leq \mathrm{X}<122.4$ & 26 & $20.1 \%$ \\
Rendah & $64.8 \leq \mathrm{X}<93.6$ & 0 & $0 \%$ \\
Sangat Rendah & $\mathrm{X}<64.8$ & 0 & $0 \%$ \\
\hline & Jumlah & $\mathbf{1 2 9}$ & $\mathbf{1 0 0 \%}$
\end{tabular}

Tabel 2. Daftar Distribusi Frekuensi Kecenderungan Kategori Perilaku Prososial

\begin{tabular}{cccc}
\hline Kategori & Kelas Interval & Frekuensi & Presentase (\%) \\
\hline Sangat Tinggi & $\mathrm{X} \geq 151.2$ & 32 & $24.8 \%$ \\
Tinggi & $122.4 \leq \mathrm{X}<151.2$ & 85 & $65.9 \%$ \\
Sedang & $93.6 \leq \mathrm{X}<122.4$ & 12 & $9.3 \%$ \\
Rendah & $64.8 \leq \mathrm{X}<93.6$ & 0 & $0 \%$ \\
Sangat Rendah & $\mathrm{X}<64.8$ & 0 & $0 \%$ \\
\hline & Jumlah & $\mathbf{1 2 9}$ & $\mathbf{1 0 0 \%}$ \\
\hline
\end{tabular}

Berdasarkan dari tabel 2 diketahui Perkembangan Moral siswa dengan kategori sangat tinggi $1.6 \%$, tinggi $78.3 \%$, sedang $20.1 \%$, rendah $0 \%$, dan sangat rendah $0 \%$. Maka dapat disimpulkan bahwa Perkembangan Moral siswa kelas X Rekayasa Perangkat Lunak di SMK Negeri 1 Tengaran dominan berkategori tinggi dengan jumlah siswa 101 dari total 129 siswa.

Berdasarkan dari tabel 3 diketahui Perilaku Prososial siswa dengan kategori sangat tinggi $24.8 \%$, tinggi $65.9 \%$, sedang $9.3 \%$, rendah $0 \%$, dan sangat rendah 0\%. Maka dapat disimpulkan bahwa Perilaku Prososial siswa kelas X Rekayasa Perangkat Lunak di SMK Negeri 1 Tengaran dominan berkategori tinggi dengan jumlah siswa 85 dari total 129 siswa.

Terdapat interpretasi koefisien korelasi menurut Sugiyono (2010) digunakan untuk memberikan penafsiran terhadap koefisien korelasi yang ditemukan tersebut besar atau kecil berdasarkan nilai $\mathrm{r}$ (koefisien korelasi). Berikut ini penjabarannya:

Tabel 4. Tabel Interpretasi Korelasi

\begin{tabular}{cc}
\hline Interval Korelasi & Tingkat Hubungan \\
\hline $0.00-0.199$ & Sangat Rendah \\
$0.20-0.399$ & Rendah \\
$0.40-0.599$ & Sedang \\
$0.60-0.799$ & Kuat \\
$0.80-1.000$ & Sangat Kuat \\
\hline
\end{tabular}

Uji hipotesis bertujuan untuk mengetahui ada atau tidak ada hubungan (korelasi) antara perkembangan moral dengan perilaku prososial siswa kelas X Rekayasa Perangkat Lunak SMK Negeri 1 Tengaran Tahun Pelajaran 2019/2020. Peneliti menggunakan teknik analisis kendall tau $b$ dengan menggunakan SPSS 20 for windows (Statistical Product and Service Solution). Hasil uji korelasi dapat dilihat pada tabel 5 .

Berdasarkan hasil uji korelasi pada tabel 5 maka diketahui nilai $r=0.291$ dengan koefisien signifikansi $0.001<0.01$, dapat ditarik kesimpulan bahwa ada hubungan yang signifikan antara

Dipublikasikan Oleh :

UPT Publikasi dan Pengelolaan Jurnal

Universitas Islam Kalimantan Muhammad Arsyad Al-Banjari Banjarmasin perkembangan moral dengan perilaku prososial siswa kelas X Rekayasa Perangkat Lunak SMK Negeri 1 Tengaran Tahun Pelajaran 2019/2020. Dari hasil koefisien korelasi pada pengujian hipotesis diketahui koefisien korelasi 0.291. Berdasarkan tabel 4 menunjukan hipotesis (H1) yang berbunyi "Ada hubungan yang signifikan antara perkembangan moral dengan perilaku prososial siswa kelas X Rekayasa Perangkat Lunak SMK Negeri 1 Tengaran Tahun Pelajaran 2019/2020" diterima, dengan tingkat hubungan yaitu antara 0.20-0.399 yang artinya rendah 
Ivan Azariya, Tritjahjo Danny Soesilo, Setyorini

Jurnal Bimbingan dan Konseling Ar-Rahman

Volume, Nomor, Tahun Edisi

e-ISSN 2477-6300

Tabel 5. Analisis Korelasi antara Perkembangan Moral dengan Perilaku Prososial

\begin{tabular}{|c|c|c|c|c|}
\hline \multicolumn{5}{|c|}{ Correlations } \\
\hline & & & Perkembangan Moral & Perilaku Prososial \\
\hline \multirow{8}{*}{$\begin{array}{l}\text { Kendall's } \\
\text { tau_b }\end{array}$} & Perkembangan & Correlation & 1.000 & $0.291^{* *}$ \\
\hline & Moral & Coefficient & & \\
\hline & & Sig. (2-tailed) & . & 0.001 \\
\hline & & $\mathrm{N}$ & 129 & 129 \\
\hline & Perilaku Prososial & Correlation & $0.291^{* *}$ & 1.000 \\
\hline & & Coefficient & & \\
\hline & & Sig. (2-tailed) & 0.001 & \\
\hline & & $\mathrm{N}$ & 129 & 129 \\
\hline
\end{tabular}

Hasil penelitian ini sejalan dengan penelitian terdahulu yang dilakukan oleh Setioasih (2016) tentang Hubungan antara Perkembangan Moral dengan Perilaku Prososial pada Remaja, yang menemukan bahwa ada hubungan positif antara perkembangan moral dengan perilaku prososial pada remaja. Penelitian Setioasih menghasilkan koefisien korelasi 0,822. Uji signifikansi menunjukkan hasil $0,000 \quad(\mathrm{p}<0,01)$ berarti korelasi kedua variabel signifikan.

Menurut Kohlberg (1995) mendefinisikan perkembangan moral sebagai penalaran terhadap nilai, penilaian sosial dan juga penilaian terhadap kewajiban yang mengikat individu dalam melakukan sebuah tindakan.

Berdasarkan data distribusi kecenderungan kategori perkembangan moral diketahui perkembangan moral siswa dengan kategori sangat tinggi $1.6 \%$, tinggi $78.3 \% \%$, sedang $20.1 \%$, rendah $0 \%$, dan sangat rendah $0 \%$, maka dapat disimpulkan bahwa perkembangan moral siswa kelas X Rekayasa Perangkat Lunak di SMK Negeri 1 Tengaran dominan berkategori tinggi dengan jumlah siswa 101 dari total 129 siswa. Dalam wawancara banyak siswa yang tidak memiliki kesadaran untuk menolong satu sama lain secara sukarela, contohnya seperti saat ada teman yang mau akan pergi membeli makanan di kantin jika ada yang ingin menitip makanan kebanyakan ingin mendapat imbalan seperti uang kembaliannya. Kondisi tersebut menyebabkan siswa tersebut tidak memiliki perkembangan moral yang baik, dengan persentase tinggi. Diartikan perkembangan moral siswa tinggi sehingga siswa dapat berkembang baik mulai dari tahap prakonvensional moralitas, konvensional dan pasca konvensional.

Menurut Fabes \& Eisenberg (1998) perilaku prososial adalah tindakan yang memberikan keuntungan pada pihak lain yang terdiri dari berbagi, menyumbang, dukungan emosional atau belarasa, pertolongan dan ketersediaan diri untuk membantu.

Berdasarkan daftar distribusi kecenderungan kategori perilaku diketahui perilaku prososial siswa dengan kategori sangat tinggi $24.8 \%$, tinggi $65.9 \%$, sedang $9.3 \%$, rendah $0 \%$, dan sangat rendah $0 \%$, maka dapat disimpulkan bahwa perilaku prososial siswa kelas X Rekayasa Perangkat Lunak di SMK Negeri 1 Tengaran dominan berkategori tinggi dengan jumlah siswa 85 dari total 129 siswa. Perilaku prososial yang tinggi diartikan bahwa siswa memiliki kemampuan dalam sharing (membagi), helping (menolong), honesty (kejujuran), cooperative (kerjasama), generosity (kedermawanan) dan mempertimbangkan hak dan kesejahteraan orang lain.

Saat peserta didik memiliki perkembangan moral yang tinggi meliputi tahap prakonvensional moralitas, konvensional dan pasca konvensional, nantinya dalam perilaku prososialnya seperti kemampuan dalam sharing (membagi), helping (menolong), honesty (kejujuran), cooperative (kerjasama), generosity (kedermawanan) dan mempertimbangkan hak dan kesejahteraan orang lain akan tinggi. Didapat hasil bahwa tingkat perkembangan moral tinggi dan tingkat perilaku prososial tinggi yang dimiliki siswa kelas $\mathrm{X}$ Rekayasa Perangkat Lunak SMK Negeri 1 Tengaran. Berarti semakin tinggi perkembangan siswa maka semakin tinggi perilaku prososial siswa.

\section{PENUTUP}

Berdasarkan hasil yang diperoleh dalam penelitian ini, maka dapat disimpulkan bahwa bahwa ada hubungan yang signifikan antara perkembangan moral dengan perilaku prososial siswa kelas X Rekayasa Perangkat Lunak SMK 
Ivan Azariya, Tritjahjo Danny Soesilo, Setyorini

Jurnal Bimbingan dan Konseling Ar-Rahman

Volume, Nomor, Tahun Edisi

e-ISSN 2477-6300

Negeri 1 Tengaran Tahun Pelajaran 2019/2020 dengan hasil nilai $r=0.291$ (tingkat hubungan remdah) dengan signifikansi $0.001<0.01$.

Dari penelitian yang telah dilakukan pada siswa kelas X Rekayasa Perangkat Lunak SMK Negeri 1 Tengaran Tahun Pelajaran 2019/2020, peneliti memberikan saran sebagai berikut: (1) Dengan hasil tingkat perkembangan moral tinggi dan tingkat perilaku prososial tinggi yang dimiliki siswa kelas X Rekayasa Perangkat Lunak SMK Negeri 1 Tengaran diharapkan siswa tetap dapat mempertahankan perkembangan moral dan perilaku prososial yang tinggi dengan demikian selain bermanfaat untuk lingkungan sekolah, keluarga, masyarakat dapat bermanfaat didunia kerja nanti. Seperti contohnya saat bekerja siswa bisa menempatkan diri lingkungan kerja jadi diperlukan perkembangan moral yang tinggi guna membina hubungan yang baik dengan rekan kerjanya nanti. Selain perkembangan moral yang tinggi perilaku prososial tinggi juga bermanfaat dengan sikap berbagi, saling menolong, sikap kejujuran, kerjasama dengan teman kerja lain, sikap kedermawanan dan mempertimbangkan hak dan kesejahteraan orang lain di tempat kerja. (2) Hasil dari penelitian ditemukan perkembangan moral siswa X Rekayasa Perangkat Lunak SMK Negeri 1 Tengaran berkategori tinggi tinggi 78.3\%, selanjutnya untuk perilaku prososial siswa siswa $\mathrm{X}$ Rekayasa Perangkat Lunak SMK Negeri 1 Tengaran berkategori tinggi $65.9 \%$. Dengan hasil tersebut diharapkan dapat menambah wawasan agar dapat membangun kesadaran untuk memperluas pengalaman bersosial. (3) Bagi peneliti selanjutnya jika melakukan penelitian dengan mengangkat topik perkembangan moral dan perilaku prososial bisa menambahkan variabel yang berbeda.

\section{REFERENSI}

Amzori, M.A. (2014). Pengaruh Perkembangan Moral terhadap Agresivitas pada Santri Pondok Pesantren Anwarul Huda Malang. Tidak Diterbitkan. Malang: Fakultas Psikologi. Universitas Islam Negeri Maulana Malik Ibrahim Malang.

Aridhona, J. (2017). Hubungan Perilaku Prososial dan Religiusitas dengan Moralpada Remaja. Jurnal Psikologi Perseptual, 2 (1).

Azwar, S. (2000). Reliabilitas Dan Validitas. Yogyakarta: Pustaka Belajar.

Baron, \& Byrne. (2003). Psikologi Sosial. Jakarta: Erlangga.

Desmita. (2015). Psikologi Perkembangan. Bandung: Remaja Rosdakarya.
Eisenberg,. N,. \& Mussen,. P.H. (1989). The roots of prosocial behavior in children.Cambridge University Press. Cambridge.

Elistantia, R., dkk. (2018). Hubungan Dukungan Sosial Orangtua dengan Perilaku Prososial. Jurnal Bimbingan Konseling, 6 (1).

Etik S.N. (2016). Hubungan antara Perkembangan Moral dengan Perilaku Prososial pada Remaja. Skripsi Tidak Diterbitkan. Malang: Fakultas Psikologi Universitas Muhammadiah Malang.

Fabes, R. A., \& Eisenberg, N. (1998). Metaanalyses of age and sex defferences in children's and adolescents' prococial behavior. Research Scientist Development. 3,129.

Faturochman. (2006). Pengantar Psikologi Sosial. Yogyakarta : Penerbit Pustaka.

Gerungan, W. A. (2004). Psikologi Sosial. Bandung: Refika Aditama.

Kohlberg, L. (1995). Tahap-tahap Perkembangan Moral. Yogyakarta: Penerbit Kanisius.

Kusumastuti, Rr.A. (2017). Hubungan antara Perkembangan Moral dengan Perilaku Prososial pada Dewasa Awal. Sarjana Thesis. Malang: Fakultas Ilmu Sosial dan Ilmu Politik. Universitas Brawijaya.

Lestari, D., \& Partini. (2015). Hubungan antara Penalaran Moral dengan Perilaku Prososial pada Remaja. Jurnal Indigenous, 13(2).

Maharani, L. (2014). Perkembangan Moral pada Anak. Jurnal Bimbingan dan Konseling, 1(2).

Santrock, J.W. 2011. Life span development. Jakarta : Penerbit Erlangga.

Soesilo, T.D. (2018). Penelitian Inferensial dalam Bidang Pendidikan. Salatiga: Satya Wacana University Press.

Sugiyono. (2010). Statistika Untuk Penelitian. Bandung: Alfabeta.

Waty, A. (2017). Hubungan Interaksi Sosial dengan Perkembangan Moral pada Remaja di SMA UISU Medan. Jurnal Psikologi Konseling. Vol 10, no 1.

Yuli A., Gusti dan Magaretha. (2010). Perilaku Prososial Ditinjau dari Empati. Dan Kematangan Emosi. Jurnal Psikologi, 2 (1).

Yusuf, S. (2002). Psikologi Perkembangan Anak dan Remaja. Bandung: PT Remaja Rosdakarya.

Yusuf, S. (2011). Psikologi Perkembangan Anak dan Remaja. Bandung: PT Remaja Rosdakarya. 